\title{
Poliklinikten Non-Reaktif Non-Stress Test Ön Tanısıyla Doğum Ünitesine Yönlendirilen Term Gebelerde Sezaryen Oranlarının ve Perinatal Sonuçların Değerlendirilmesi
}

\section{Investigation of Cesarean Rates and Perinatal Outcomes of Term Pregnancies Referred to the Delivery Unit from the Outpatient Clinic with Pre-Diagnosis of Non-Reactive Non-Stress Test}

${ }^{1}$ İsa Şükrü ÖZ

\author{
${ }^{1}$ Afyon Devlet Hastanesi, Kadın Hastalıkları ve Doğum Kliniği, Afyon, Turkiye
}

İsa Şükrü Öz: https://orcid.org/0000-0001-8849-2705

\section{ÖZ}

Amaç: Rutin gebelik takipleri için hastanemize başvuran gebelerde, fetal iyilik hallerinin takibinde non-reaktif non-stress test ön tanısı alıp, doğumhaneye yönlendirilen gebelerin sezaryen oranları ve perinatal sonuçları araştırılmıştır.

Materyal ve Metot: Ocak 2018-Aralık 2018 tarihleri arasındaki 1 yıllık süre zarfinda $37-41$ haftalık gebeliği mevcut olup, rutin gebelik kontrolleri sirasında non-reaktif non-stress test ön tanısı alıp, doğumhaneye yönlendirilen toplam 100 adet gebenin verileri retrospektif olarak tarand. Non- reaktif non- stress teste sebep olabilecek risk faktörleri bulunan yüksek riskli gebeler araştırmaya dahil edilmedi. Araştırmada gebelerin doğum şekilleri kayıt altına alındı ve bunlardan non-reaktif non-stress teste bağlı sezaryen olanlar araştırıld.

Bulgular: Çalışmamız kapsamında non-reaktif nonstress teste bağlı doğumhaneye yönlendirilen 100 hastanın; 88'i fetal canlandırma işlemleri sonrası non-stress testleri reaktivite göstermiştir. Geriye kalan 12 hastaya da fetal canlandırma işlemleri uygulanmış ancak fetal canlandırma ve diğer işlemlerden sonuç alınmayınca acil sezaryen ile doğumları gerçekleşmiştir. Non-rektif non stress test tanıs1 alıp doğurtulan gebelerdeki primer sezaryen oranı \%23,6 olarak görülmüştür. Perinatal sonuçlar açısından fetal iyilik hali takibinde non-reaktif stress test tanıs1 alıp doğumu olanlar ile non-reaktif non-stress test tanıs1 almayıp doğuranlar arasında istatistiksel anlamlı bir fark yoktur $(\mathrm{p}>0,05)$.

Sonuç: Non-reaktif non-stress test tanısı alıp doğurtulan gebelerde primer sezaryen oranı artmıștır.

Anahtar Kelimeler: Non-reaktif, non-stress test, primer sezaryen, sezaryen oranı

\begin{abstract}
Objective: Cesarean rates and perinatal outcomes of pregnant women who admitted to our hospital for routine follow-up and were referred to the delivery room with prediagnosis of non-reactive nonstress test were investigated. Materials and Methods: A total of 100 pregnant women of 37-41 weeks gestation who were pre-diagnosed with non-reactive nonstress test during routine follow-up and referred to the delivery unit between January 2018 and December 2018 were retrospectively evaluated. High-risk pregnant women with risk factors that may have contributed to non-reactive nonstress test were not included in the study. Modes of delivery were documented and cesarean deliveries due to non-reactive nonstress test were investigated.

Results: Of the 100 patients referred to the delivery room due to non-reactive nonstress test, 88 showed reactive nonstress test following fetal resuscitation. The remaining 12 patients were nonresponsive despite fetal resuscitation and other efforts and underwent emergency cesarean delivery. The primary cesarean rate of delivered pregnancies diagnosed with non-reactive nonstress test was $23.6 \%$. There was no statistically significant difference between pregnancies diagnosed and not diagnosed with non-reactive nonstress test according to perinatal outcomes in fetal wellbeing follow-up ( $\mathrm{p}>0.05)$.

Conclusion: Primary cesarean rate was higher in delivered pregnancies diagnosed with non-reactive nonstress test.

Keywords: Cesarean rate, non-reactive, non-stress test, primary cesarean
\end{abstract}

\section{Sorumlu Yazar / Corresponding Author:}

İsa Şükrü Öz

Afyon Devlet Hastanesi, Kadın Hastalıkları ve Doğum Kliniği,

Afyon, Turkiye

Tel: 05069588588

E-mail: isaoz80@gmail.com
Yayın Bilgisi / Article Info:

Gönderi Tarihi/ Received: 31/12/2019

Kabul Tarihi/ Accepted: 15/10/2020

Online Yayın Tarihi/ Published: 30/12/2020

Atıf / Cited: Öz İŞ. Investigation of Cesarean Rates and Perinatal Outcomes of Term Pregnancies Referred to the Delivery Unit From the Outpatient Clinic with Pre-Diagnosis of Non-Reactive Non-Stress Test . Online Türk Sağllk Bilimleri Dergisi 2020;5(4):641-647. doi: 10.26453/otjhs.668671 


\section{INTRODUCTION}

Nonstress test (NST) is one of the most important indicators of fetal wellbeing. Fetal wellbeing refers to the in-utero fetus being safe and not in stress. NST is performed by placing two transducers on the mother's abdomen with the help of a belt, in which one of the transducers monitors fetal heart rate while the other shows uterine contractions, allowing evaluation of the status of the fetus in the womb. NST is a noninvasive test and is usually applied to pregnant women of and further than 28 weeks gestation. ${ }^{1}$

The heart rate of a healthy fetus is between 120-160 bpm. Fetal tachycardia refers to heart rate over 160 bpm, and fetal bradycardia below $110 \mathrm{bpm} .{ }^{1,2}$ The NST results are interpreted by printing the information from the probes onto an NST paper. Reactive NST is a minimum of two fetal movements over 20 minutes and a heart rate increase of more than 15 beats associated with this fetal movement, that prolongs for a minimum of 15 seconds. Reactive NST result is a good indicator of the fetus receiving sufficient oxygenation. Non-reactive NST refers to situations in which reactive NST does not occur. The accelerated heart rate of more than 15 beats continuing for 15 seconds is absent in non-reactive NST. In these cases, the test duration is extended. If the nonreactive nonstress test do not become reactive within the period extended up to 40 minutes, the NST is concluded as non-reactive NST. ${ }^{1}$ While there are many causes of non-reactive NST, the most commonly seen cause in clinical observations is fetal sleep. The most important reason why clinicians are worried when they encounter non-reactive NST is that it may also be an indicator of fetal stress. ${ }^{2}$ Not to mention, fetal mortality rate in the week following non-reactive NST result is $3-5 / 1000$ in pregnant women with non-reactive NST. False positivity of non-reactive NST is also relatively high. This situation leaves clinicians caught in the middle when they encounter non-reactive NST, causing them to act defensively, and give preference in favor of cesarean section.

In this study we investigated, cesarean rates and perinatal outcomes of pregnant women who were pre-diagnosed with non-reactive non-stress test and referred to delivery room.

\section{MATERIALS AND METHODS}

The study was conducted in accordance to the principles of the Helsinki Declaration. The study received ethics approval from the Zonguldak Bulent
Ecevit University Ethics Committee (Date: 28/02/2018, decision no: 2018-690-28/02) and informed written consent was obtained from all study participants.

A total of 100 pregnant women of 37-41 weeks gestation who were pre-diagnosed with non-reactive nonstress test during routine follow-up and referred to the delivery unit between January 2018 and December 2018 were retrospectively evaluated. Pregnant women who were considered high-risk and with conditions that may contribute to non-reactive NST (diabetes, hypertension, drugs, comorbidities) were excluded from the study. The number of gravida, parity, gestational age, smoking status, delivery type, and referrals to external centers of the pregnant women who participated in the study were recorded. When patients referred from the outpatient clinic with pre-diagnosis of non-reactive NST were initially admitted to the delivery unit, fetal status was reevaluated along with cervical dilation, effacement, and position evaluations and patients were put under surveillance. Ultrasound evaluation was repeated and fetal biometry, amniotic fluid index, placental position, fetal heart rate, and fetal weight were documented. Patients rested for 1-2 minutes after ultrasound evaluation. During this time, blood glucose levels were measured with finger prick. Then, NST were repeated and the patients with persistent nonreactive NST were asked to lie on their left sides, and if necessary, fetal resuscitation was attempted by administering nasal oxygen and 500 cc solution containing $5 \%$ dextrose. Thus, the length of repeated NSTs were extended to over 40 minutes. NST that did not show reactivity during at least 40 minutes were considered non-reactive. Patients who showed reactivity following fetal resuscitation and without pathology in ultrasound examination were discharged. Patients with non-reactive NST results underwent contraction stress test (CST). Patients with negative CST were followed-up. Those with positive or uncertain CST results underwent cesarean action on account of fetal stress. Furthermore, patients were also evaluated according to NST and amniotic fluid index. Patients showing reactive NST and normal amniotic fluid index were discharged, while those not showing reactivity or with abnormal amniotic fluid index indicated labor. Labor induction was initiated in appropriate pregnancies according to Bishop scores. It was also recorded whether or not patients referred to the delivery unit with prediagnosis of non-reactive NST were referred to a 
higher institute university hospital. Need for newborn intensive care following birth was also recorded.

Statistical analysis was performed using the SPSS 22.0 package program for Windows. Numerical variables were expressed as mean \pm standard deviation. Categorical variables were expressed as number and percentage. Mann Whitney U test was used to compare two groups according to variables. The value of $\mathrm{p}<0.05$ was considered statistically significant.

\section{RESULTS}

Of the 100 patients evaluated in the scope of the study, 46 were discharged following successful fetal resuscitation and later had normal births (Table 1). Twenty-nine patients were hospitalized due to nonreactive NST and were discharged following fetal resuscitation but later underwent primary cesarean section due to causes unrelated to non-reactive NST. Nine of the patients who were referred to the delivery room with non-reactive NST diagnosis underwent primary cesarean section due to non-reactive NST. Additionally, three of the patients referred to the delivery with non-reactive NST diagnosis underwent repeated cesarean section. Of the patients referred to the delivery room with non-reactive NST diagnosis, 13 had history of prior cesarean section and were discharged following fetal resuscitation, but later underwent repeated cesarean section at their time of labor. In other words, a total of 12 patients diagnosed with non-reactive NST underwent emergency cesarean section and 9 of them were primary cesarean sections. Primary cesarean unrelated to non-reactive NST is actually 3.2 times more frequent. None of the 100 participants of our study had been referred to the higher institute university hospital. One $(8.3 \%)$ of the newborns who were born from cesarean section due to non-reactive NST diagnosis was transferred to the intensive care unit. The other 11 newborns did not require intensive care. There was no statistically significant difference between both groups according to the newborn's need for intensive care $(\mathrm{p}>0.05)$.

Primary cesarean rate of the 12 patients who underwent labor due to non-reactive NST was $23.6 \%$. Differences according to non-reactive NST diagnosis in patients who underwent primary cesarean section was assessed with Mann Whitney U test. Rate of non-reactive NST diagnosis was found to be significantly higher in patients who underwent primary cesarean section $(\mathrm{p}=0.005,<0.05)$.
The primary cesarean rate of patients who underwent emergency cesarean section due to nonreactive NST was $75 \%$ (Figure 1 ).

\section{DISCUSSION AND CONCLUSION}

Reactive NST refers to presence of minimum of two heart rate accelerations of more than $15 \mathrm{bpm}$ lasting more than 15 seconds, indicating the fetus is not under stress. In other words, reactive NST predicts good perinatal outcomes. ${ }^{3,4}$ However, according to the literature, the opposite of this statement is not true. In other words, non-reactive NST does not necessarily indicate that the fetus is under stress. There are studies that show that the fetus may be normal in non-reactive NST. ${ }^{5}$ In fact, in these studies, Doppler examinations were performed on patients with nonreactive NST and normal results were yielded. ${ }^{5} \mathrm{Ad}-$ ditionally, various factors effect the reactivity of NST, including reasons such as fetal sleep, maternal glucose level, maternal drug use, maternal comorbidities, and maternal exercise. ${ }^{6-8}$ In our study, patient women were rested following ultrasound examination in the emergency obstetric unit. Blood glucose levels of the pregnant women were also recorded. One study indicated that NST along with Doppler examination not only showed fetal wellbeing but could also be helpful, and emphasized that there was a positive correlation between reactive NST and Doppler parameters. ${ }^{9-10}$ Other studies on the subject also supported this assessment and Doppler studies on the middle cerebral artery (MCA) have been especially emphasized. During evaluation of MCA, systole/diastole ratio (S/D) is most commonly assessed, and S/D ratio below 3 in the last trimester of gestation is significant in terms of hypoxia. ${ }^{10,11}$ In our study, low-risk pregnancies were investigated and MCA Doppler examinations were not performed. Another study that shares our opinion also argued that Doppler examination was unnecessary in showing fetal wellbeing in low-risk pregnancies due to its low sensitivity. ${ }^{12}$ In the presence of nonreactive NST, fetal sleep should also be considered. To rule out fetal sleep, external palpation of the mother's abdomen, extended NST, administration of $5 \%$ dextrose solution to the mother, nasal oxygen, and noninvasive vibroacoustic stimulation test is recommended. ${ }^{13-15}$ Hasanpour et al. ${ }^{16}$ reported that $80 \%$ of non-reactive NST gained reactivity 30 minutes later following oral glucose consumption and vibroacoustic stimulation test. Aside from fetal sleep, the fact that non-reactive NST result may indicate fetal stress is a fact that should always be kept 
in mind. Various procedures may be performed to rule out fetal stress in the presence of non-reactive NST. The most important of these are the contraction stress test (CST) and modified biophysical profile. In our study, these procedures were not carried out.

In another study, CST and biophysical profile following non-reactive NST results showed positive results. In the same study, it was emphasized that fetal age was also important in non-reactive NSTs and it was concluded that non-reactive NST results could be seen in up to half of pregnant women with fetal age between 24 - 28 weeks without any nervous system pathology. Non-reactive NST rate is approximately $15 \%$ in pregnant women without nervous system pathology with fetal age between 28-32 weeks. $^{17}$

As mentioned in previous publications, not all nonreactive NSTs indicate fetal stress, in fact the absence of fetal stress is a higher possibility. ${ }^{17,18}$ Supportive of this notion, in our study newborns delivered with cesarean section due to non-reactive NST did not have significant difference in need for intensive care compared to other births, and false positivity accounts for $50-80 \%$ of non-reactive NSTs. However, clinicians nowadays do not want to face legal issues that may arise from these situations, and prefer to act defensively and perform cesarean deliveries. Furthermore, of the 12 patients with ongoing non-reactive NST despite fetal resuscitation efforts, 9 underwent primary cesarean section, and 3 repeated cesarean sections, with the decision of emergency labor. In other words, cesarean birth was performed in all 12 of the patients. Only 9 patients underwent primary cesarean section, but what was more important was to determine whether or not non-reactive NST caused primary cesarean section and whether or not it affected cesarean rates. This is because cesarean delivery was already planned in repeated cesarean pregnancies and non-reactive NST only led to cesarean section performed earlier than planned, while it did not change the decision for cesarean section. However, primary cesarean births were cases in which birth may have occurred normally when the time for labor would have come, had there not been non-reactive NST. Therefore, the important aspect is the number of primary cesarean births and how many of these cesarean s were associated with non-reactive NST.

Aktulay et al. ${ }^{19}$ conducted a study on 405 pregnancies with pre-diagnosis of non-reactive NST and reported primary cesarean rate of $43.06 \%$. The same study also indicated non-reactive NST could benefit from that supportive measures such as the mother laying to the left, dextrose solutions, and oxygen administration leading to reactivity, and that nonreactive NST contributed to increased primary cesarean rates.

Although primary cesarean rate due to non-reactive NST diagnosis was increased to $23.6 \%$, non-reactive NST diagnosis was not associated with difference in perinatal outcomes compared to births unrelated to non-reactive NST.

In conclusion; we detected, pregnant women with non-reactive NST mostly refer their physicians to cesarean section. However, it should be known that there is no significant difference in perinatal results. We recommend emergency caesarean indication decisions should be reviewed after close follow-up and re-examination of these pregnant women.

Ethics Committee Approval: Our study approved by the Zonguldak Bulent Ecevit University Ethics Committee (Date: 28/02/2018, decision no: 2018 690-28/02).

Conflict of Interest: No conflict of interest was declared by the authors.

Author Contributions: Concept-İŞÖ SupervisionİŞÖ; Materials-İŞÖ; Data Collection and/or Processing-İSÖ; Analysis and/ or Interpretation-İŞÖ; Writing-İŞÖ.

Peer-review: Externally peer-reviewed.

\section{REFERENCES}

1. Ocak V, Sen C, Demirkiran F, Colgar U, Oçer F, Kilavuz O. FHR monitoring and perinatal mortality in high-risk pregnancies. Eur J Obstet Gynecol Reprod Biol. 1992;44(1):59-63.

2. Hoh JK, Park MI, Park YS, Koh SK. The significance of amplitude and duration of fetal heart rate acceleration in non-stress test analysis. Taiwan J Obstet Gynecol. 2012;51(3):397-401.

3. Ocak V, Gezer A. Antenatal fetal iyilik halinin belirlenmesi. In: Beksac MS, Demir N, Koç A, Yüksel A, eds. Obstetrik; Maternal-Fetal Tıp \& Perinataloji. İstanbul, Nobel Tip Kitabevleri; 2001:1166-1178.

4. Druzin ML, Gratacos J, Paul RH. Antepartum fetal heart rate testing IV. Predictive reability of "normal" tests in the prevention of antepartum death. Am J Obstet Gynecol. 1980;137:746-747.

5. Farmakides G, Schulman H, Winter D et al. Prenatal surveillance using nonstes testing and Dop- 
pler velocimetry. Obstet Gynecol. 1988;71:184187.

6. Zimmer EZ, Paz Y, Goldstick O, Beloosesky R, Weiner Z. Computerized analysis of fetal heart rate after maternal glucose ingestion in normal pregnancy. Obstet Gynecol. 2000;93:57-60.

7. Farmakides G, Schulman H, Winter D et al. Prenatal surveillance using nonstes testing and Doppler velocimetry. Obstet Gynecol. 1988;71:184187.

8. Webb KA, Wolfe LA, McGrath MJ. Effects of acute and chronic maternal exercise on fetal heart rate. J Appl Physiol. 1994;77:2207-2213.

9. Arduini D, Rizzo G, Soliani A, Romanini C. Doppler velocimetry versus nonstres test in the antepartum monitoring of low-risk pregnancies. J Ultrasound Med. 1991;10:331-335.

10. Özcan N. Obstetrik Doppler sonografi. In: Renkli Doppler Ultrasonografi. 17. Türk Radyoloji Kongresi. 27-31 Ekim, 2000, İstanbul.

11. Ogunyemi D, Stanley R, Lynch C, Edwards D, Fukushima $\mathrm{T}$. Umblical artery velocimetry in predicting perinatal outcome with intrapartum fetal distress. Obstet Gynecol. 1992;80:377-380.

12. Wladimiroff JW, Huisman TWA, Stewart PA. Normal fetal arterial and venous flow-velocity waveforms in early and late gestation. In: Jaffe $\mathrm{R}$, Warsof SL, eds. Color Doppler Imaging in Obstetrics and Gynecology. New York, McGrawHill, Inc; 1992:155-173.

13. Ohel G, Birkenfeld A, Rabinowitz R, Sadovsky E. Fetal response to vibratory acoustic stimulation in periods of low heart rate reactivity and low activity. Am J Obstet Gynecol. 1986;154 (3):619-621.

14. Goonewardene M, Hanwellage K. Fetal acoustic stimulation test for early intrapartum fetal monitoring. Ceylon Med J. 2011;56(1):14-18.

15. Bartnicki J, Ratanasiri T, Meyenburg M, Saling E. Effect of the vibratory acoustic stimulation on fetal heart rate patterns of premature fetuses. Int $\mathbf{J}$ Gynaecol Obstet. 1992;37(1):3-6.

16. Hasanpour S, Raouf S, Shamsalizadeh N, Bani S, Ghojazadeh M, Sheikhan F. Evaluation of the effects of acoustic stimulation and feeding mother stimulation on non-reactive non-stress test: a randomized clinica trial. Arch Gynecol Obstet. 2013;287(6):1105-1110.

17. Devoe LD, Jones CR. Nonstress test: evidencebased use in high-risk pregnancy. Clin Obstet Gynecol. 2002;45(4):986-992.
18. Tonguç E, Moraloğlu Ö, Var T, Engin Üstün Y. Antepartum fetal tests. J Gynecol-Obstet Neonatal. 2009;6:953-957.

19. Aktulay A, Engin Üstün Y, Yapar Eyı EG, Yörük Ö, Hançerlıgulları N, Mollamahmutoglu L. Non-reaktif NST ön tanısının düşük riskli gebeliklerde değerlendirilmesi. JinekolojiObstetrik ve Neonatoloji Tip Dergisi. 2013;10 (37):1542-1544. 
Table 1.Clinical features of patients.

\begin{tabular}{|l|c|c|c|c|}
\hline & All patients & $\begin{array}{c}\text { Births due } \\
\text { to non- } \\
\text { reactive } \\
\text { NST }\end{array}$ & $\begin{array}{c}\text { Births unre- } \\
\text { lated to non- } \\
\text { reactive NST }\end{array}$ & $\begin{array}{c}\text { p value / Mann } \\
\text { Whitney U test } \\
\text { (NST related - } \\
\text { unrelated) }\end{array}$ \\
\hline Patient number & 100 & 12 & 88 & 0.098 \\
\hline $\begin{array}{l}\text { Gestation week } \\
\text { (Mean } \pm \text { SD) }\end{array}$ & $38.51 \pm 1.29$ & $39.25 \pm 1.71$ & $38.41 \pm 1.20$ & $* \mathbf{0 . 0 0 5}$ \\
\hline $\begin{array}{l}\text { Primary C/S Number } \\
\text { Percentage }\end{array}$ & 38 & 9 & 29 & $76 \%$ \\
\hline $\begin{array}{l}\text { Gravida } \\
\text { Mean } \pm \text { SD) }\end{array}$ & $2.08 \pm 0.93$ & $1.92 \pm 1.08$ & $2.10 \pm 0.91$ & 0.45 \\
\hline Parity (Mean \pm SD) & $0.82 \pm 0.78$ & $0.58 \pm 0.79$ & $0.85 \pm 0.78$ & 0.232 \\
\hline $\begin{array}{l}\text { Discharge following fetal } \\
\text { resuscitation and NST repeat } \\
\text { Mean } \pm \text { SD) }\end{array}$ & $0.79 \pm 0.41$ & $0.08 \pm 0.29$ & $0.89 \pm 0.32$ & $* \mathbf{0 . 0 0 0}$ \\
\hline
\end{tabular}

${ }^{*} \mathrm{p}<0.05$ is statistically significant; SD: Standart Deviation. C/S: Ceserean/Section. 


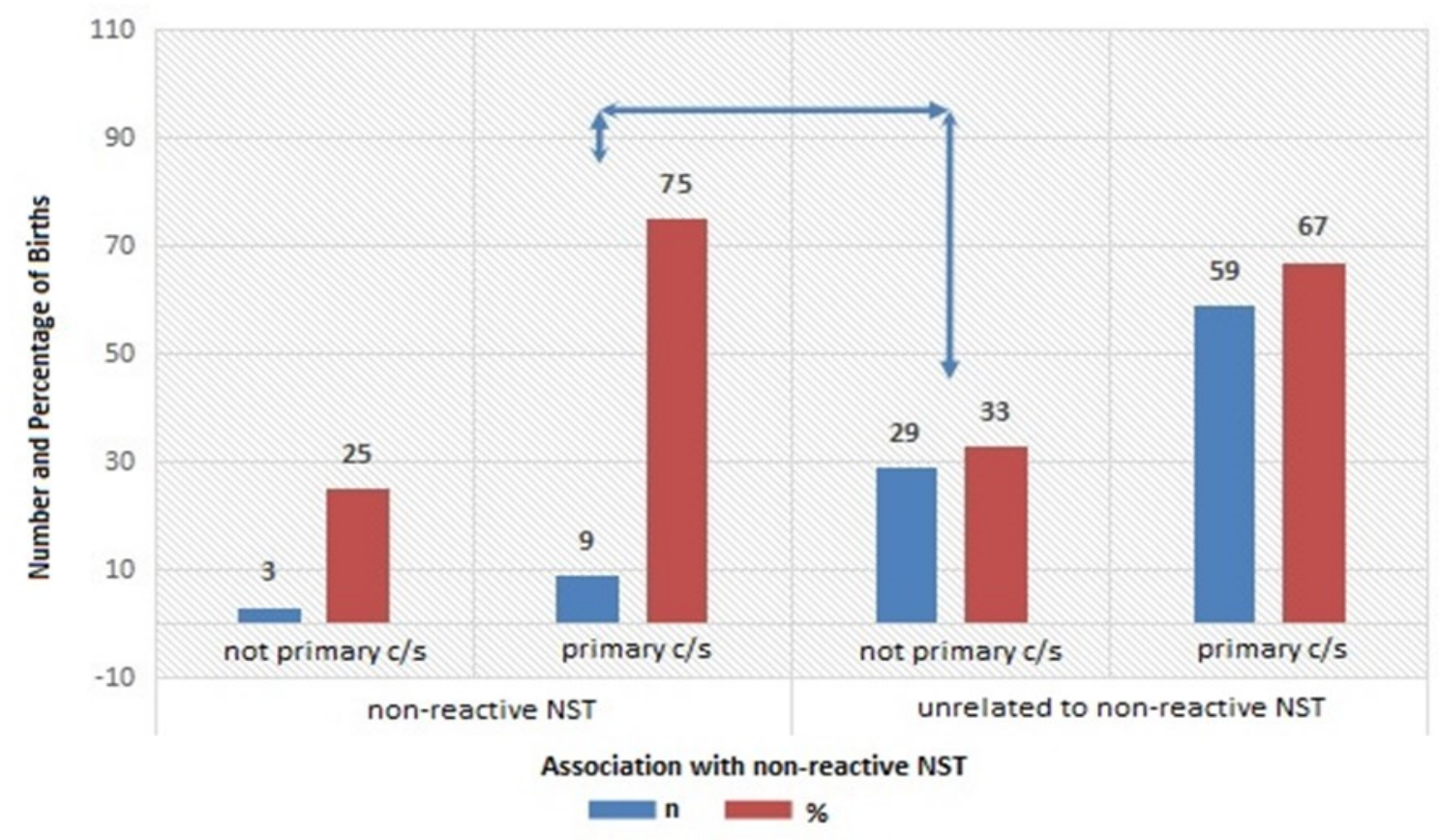

Figure 1. The primary cesarean rate of patients. 